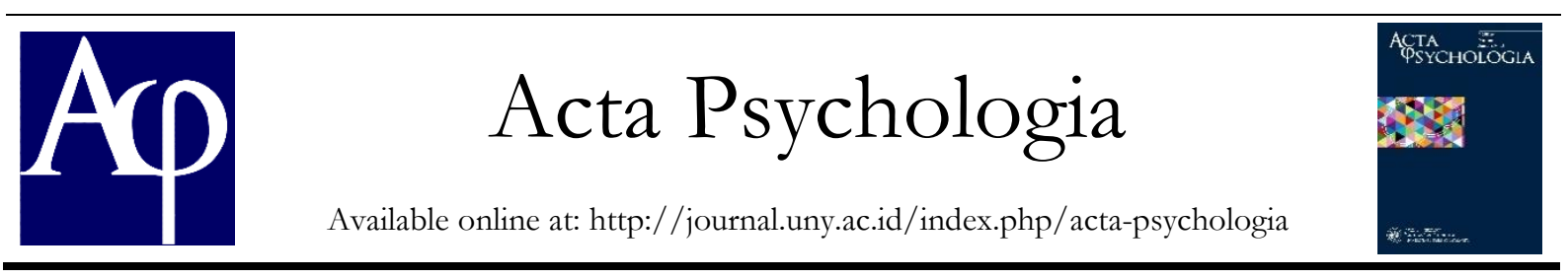

\title{
Anteseden Cyberloafing pada Karyawan Perusahaan Start-up
}

\author{
Mutbi'ah Arzabra, Rabmatika Kurnia Romadhani \\ Program Studi Psikologi, Universitas Negeri Yogyakarta; Jl. Colombo No. 1 Sleman Yogyakarta, \\ 55281 \\ muthiah.azzahra2016@student.uny.ac.id
}

\begin{abstract}
Abstrak
Bentuk withdrawal yang banyak terjadi di tempat kerja yaitu cyberloafing. Cyberloafing adalah penggunaan akses internet, email, dan pesan instan untuk kesenangan pribadi karyawan di luar pekerjaan. Penelitian ini bertujuan mengetahui cyberloafing pada karyawan perusahaan start-up dan mengetahui anteseden cyberloafing. Penelitian ini merupakan penelitian korelasional yang dilakukan pada 66 karyawan dari berbagai perusahaan start-up. Pengambilan sampel dalam penelitian ini menggunakan teknik accidental sampling. Pengumpulan data menggunakan skala cyberloafing dan skala anteseden cyberloafing dengan skala likert yang telah diuji validitas dan reliabilitasnya. Data hasil penelitian dianalisis dengan menggunakan analisis regresi linear berganda, diperoleh nilai $\beta$ sebesar 0,484 pada variabel sifat kepribadian, tuntutan dan dukungan kerja $(\beta 0,603)$, gangguan pekerjaan dan keluarga $(\beta 0,188)$, serta kebijakan perusahaan $(\beta 0,488)$. Hasil penelitian ini menunjukkan penemuan yang baru dalam penelitian cyberloafing. Hasil analisis regresi berganda tersebut menunjukkan bahwa anteseden cyberloafing yang memiliki pengaruh terhadap cyberloafing adalah tuntutan dan dukungan pekerjaan. Sedangkan, anteseden lain yaitu sifat kepribadian, gangguan pekerjaan dan rumah, serta kebijakan perusahaan tidak memiliki pengaruh terhadap cyberloafing.
\end{abstract}

Kata Kunci: cyberloafing, anteseden cyberloafing, karyawan start-up

\begin{abstract}
The most widespread form of withdrawal that occurs in the workplace is cyberloafing. Cyberloafing is the use of internet access, email, and instant messaging for employees personal enjoyment outside of their work. This study aims to determine cyberloafing among employees of start-up companies and to determine the antecedents of cyberloafing among employees of start-up companies. This research is a quantitative study with a correlational research design which was conducted on 66 employees from various start-up companies. Sampling in this study using accidental sampling technique. Collecting data using cyberloafing scale and cyberloafing antecedent scale with a Likert scale model that has been tested for validity and reliability. The research data were analyzed using multiple linear regression analysis, obtained a $\beta$ value 0,484 of the variable personality traits, job demand and resources $(\beta 0,603)$, interference work and family $(\beta 0,188)$, and company policy $(\beta 0,488)$. The results of this study indicate new findings in cyberloafing research. The results of multiple regression analysis show that the antecedents of cyberloafing are job demands and resources. Meanwhile, other antecedents, namely personality traits, interference work and family, and company policies have no effect on cyberloafing
\end{abstract}

Keywords: cyberloafing, antecedents of cyberloafing, employees of start-up

\section{Pendahuluan}

Hasil survei Asosiasi Penyelenggara Jasa Internet Indonesia (APJII) tahun 2018 mengenai pertumbuhan penggunaan internet di Indonesia memperlihatkan bahwa jumlah pengguna internet semakin meningkat dengan rata-rata pertumbuhan sebesar $10,12 \%$ setiap tahunnya pada periode 2018-2023. Pertumbuhan penggunaan internet yang cukup tinggi 
tersebut membuka peluang besar bagi banyak perusahaan untuk berlomba beralih menuju bisnis berbasis elektronik dengan menggunakan internet di berbagai proses kerjanya (Rajah \& Lim, 2011).

Hadirnya internet telah memberi banyak kemudahan dan keuntungan bagi para karyawan yang pada akhirnya akan berimbas positif pada perusahaan. Namun, di sisi lain internet juga dapat membawa dampak negatif apabila disalahgunakan. Penyalahgunaan internet yang termasuk ke dalam bentuk withdrawal di tempat kerja yaitu cyberloafing. Cyberloafing merupakan topik relatif baru dalam penelitian ilmiah di Indonesia sehingga masih belum mendapat banyak perhatian, terutama pada anteseden yang mempengaruhinya. Selain itu, penelitian cyberloafing sebelumnya lebih banyak dilakukan di perusahaan yang masih bersifat konvensional dan belum banyak menyentuh perusahaan start-up yang kini banyak bermunculan. Dengan demikian masih belum bisa dipastikan kecocokan anteseden yang mempengaruhi cyberloafing di perusahaan start-up, terutama pada anteseden individu, pekerjaan, dan organisasi.

\section{Cyberloafing didefinisikan sebagai} kegiatan karyawan mengakses internet pada jam kerja untuk kepentingan pribadi yang tidak terkait dengan pekerjaan (Askew, 2012). Definisi lain mengenai cyberloafing juga dikemukakan oleh Colquitt, LePine dan Wesson (2015). Cyberloafing merupakan penggunaan akses internet, email, dan pesan instan untuk kesenangan pribadi karyawan di luar pekerjaannya. Menurut Colquitt, LePine dan Wesson (2015), cyberloafing termasuk salah satu bentuk withdrawal/penarikan diri secara psikologis di tempat kerja. Sebagian besar karyawan yang melakukan penarikan diri dimotivasi oleh keinginan untuk melarikan diri atau menghindari sesuatu yang tidak menyenangkan di tempat kerja. Karyawan yang melakukan penarikan diri secara psikologis ini seolah-olah terlihat bekerja padahal pikirannya sedang sibuk melakukan hal lain diluar pekerjaannya.

$$
\text { Van Doorn (2011) dalam }
$$
penelitiannya menampilkan gyberloafing sebagai konstruk multi-dimensi, yaitu melihat cyberloafing terdiri dari aktivitas dan perilaku. Aktivitas cyberloafing merupakan suatu bentuk kegiatan penggunaan internet di tempat kerja yang bukan digunakan untuk bekerja dan dilakukan pada saat jam kerja berlangsung. Sedangkan, perilaku cyberloafing lebih mengarah pada alasan karyawan melakukan aktivitas cyberloafing

Menurut Van Doorn (2011) terdapat tiga anteseden yang mempengaruhi cyberloafing yaitu individu, pekerjaan, dan organisasi. Anteseden individu dapat dilihat dari sifat kepribadian seorang karyawan. Sifat kepribadian yang sering digunakan dalam penelitian terkait dengan internet adalah Big Five Model (Tresyagati, 2014; Jia, Ronnie, \& Steven, 2013; Buckner, Castille, \& Sheets, 2012). Big Five Model mengacu pada lima ciri kepribadian yaitu extraversion, agreeableness, conscientiousness, neuroticism, dan openness. Hasil penelitian yang dilakukan Jia, Ronnie, dan Steven (2013) terkait dengan cyberloafing dan personality traits menemukan: (1) adanya hubungan positif antara extraversion dengan cyberloafing, (2) conscientiousness, emotional stability, dan openness berhubungan negatif dengan cyberloafing, (3) agreeableness ditemukan berhubungan namun tidak signifikan.

Anteseden pekerjaan yang mempengaruhi cyberloafing adalah tuntutan dan dukungan kerja serta gangguan pekerjaan dan keluarga. Tuntutan pekerjaan menggambarkan sejauhmana lingkungan kerja mengandung rangsangan yang membutuhkan upaya kognitif, emosional, ataupun fisik yang berkelanjutan. Sedangkan, dukungan kerja mengacu pada cadangan energik yang dapat disadap ketika individu harus mengatasi rangsangan penuh tekanan atau stress atau dapat dikatakan dukungan kerja berfungsi untuk membantu 
karyawan mengatasi tuntutan kerja dan segala konsekuensi yang mungkin terjadi. Penelitian Blanchard dan Henle (2008) menunjukkan bahwa karyawan yang mendapat tuntutan kerja rendah akan memiliki kemungkinan terlibat lebih tinggi dengan cyberloafing karena memiliki waktu luang lebih banyak. Selain itu dikatakan bahwa tuntutan kerja yang tinggi ternyata akan menghasilkan kemungkinan peningkatan juga pada cyberloafing. Gangguan pekerjaan dan keluarga pada anteseden pekerjaan ini menggambarkan ketidakseimbangan pada salah satunya (pekerjaan atau keluarga saja). Tuntutan pekerjaan yang tinggi akan mempengaruhi keseimbangan antara pekerjaan dan keluarga secara negatif sehingga dapat menyebabkan resiko karyawan mengalami kelelahan. Dengan demikian, baik secara langsung maupun tidak langsung akan menunjukkan efek terhadap cyberloafing sebagai perilaku pemulihan.

Anteseden organisasi tersusun dari kebijakan-kebijakan yang digunakan oleh perusahaan. Beberapa perusahaan menggunakan kebijakan internet untuk mengontol penggunaan internet di tempat kerja. Lim dan Theo (2005) menuturkan bahwa kebijakan internet memiliki tujuan untuk mengatur perilaku karyawan dalam penggunaan internet yang terbukti memainkan peran penting terkait perilaku cyberloafing. Terdapat konsep baru dari sebuah kebijakan organisasi yang mana menawarkan karyawan untuk membeli alat atau perangkat keras (hardware/device) sendiri dari anggaran organisasi. Kebijakan ini masih lemah dan kurang kontrol dari organisasi terhadap perangkat yang digunakan. Kebijakan ini diteliti karena dimungkinkan karyawan akan memiliki keterlibatan lebih pada perilaku cyberloafing. Kebijakan yang terakhir adalah kebijakan cara kerja baru ini merupakan hasil sumbangsih dari praktik kerja dalam hal fleksibilitas waktu dan tempat dengan memberikan karyawan pekerjaan yang dapat dikerjakan di luar tempat kerja.
Tantangan dari kebijakan ini menurut Kurland dan Bailey (dalam Van Doorn, 2011) terkait dengan pemantauan kinerja, kontrol manajerial, dan koordinasi kerja yang memungkinkan karyawan terlibat dalam aktivitas maupun perilaku cyberloafing.

Ries (2018) mendefinisikan start-up sebagai institusi yang dirancang untuk menciptakan produk atau jasa baru pada suatu kondisi ketidakpastian yang ekstrem. Perusahaan start-up diartikan sebagai organisasi yang dibentuk untuk mencari model bisnis yang scalable dan repeatable (Steve Blank dalam Perdani, Widyawan, dan Paulus, 2018). Yudhanto (2018) menjelaskan beberapa karakteristik dari perusahaan start-up yaitu usia bisnis usaha kurang dari tiga tahun, inovasi dan keunikan ide, minim SDM, struktur organisasi multitasking, semangat idealism, kondisi ketidakpastian, didominasi teknologi, menggunakan media internet, dan mudah beradaptasi.

Kajian pada penelitian Van Doorn (2011) yang bertujuan menggambarkan cyberloafing sebagai konstruk multi-dimensi yang membedakan antara aktivitas dan perilakunya serta menempatkan cyberloafing dalam kerangka untuk mengeksplorasi hubungannya dengan anteseden dan konsekuensi yang membersamainya. Penelitian ini dianalisis menggunakan teknik analisis regresi berganda dengan sampel 172 manajer dan konsultan di Belanda. Mayoritas responden adalah konsultan sebanyak $82 \%$ dan $90,1 \%$ responden adalah laki-laki. Hasil dari penelitian ini menunjukan konstruksi multi-dimensi cyberloafing valid, prevalensi cyberloafing membuktikan bahwa aktivitas dan perilaku cyberloafing terjadi dalam lingkungan kerja, semua anteseden cyberloafing terkait dengan aktivitas dan perilaku cyberloafing, serta adanya kontribusi positif gyberloafing bagi karyawan dan organisasi. Ditemukan enam anteseden yang paling signifikan memiliki hubungan terhadap gyberloafing baik aktivitas maupun perilakunya yaitu internet policy, bring 
your own hardware, physical resources, emotional resources, interference family-work, dan conscientiousness

\section{Metode Penelitian}

\section{Jenis penelitian}

Pendekatan kuantitatif dengan desain penelitian korelasional kausal dilakukan dalam penelitian ini. Dari pendekatan ini akan diperoleh informasi terkait dengan hubungan timbal-balik yang terjadi pada variabel terkait (Azwar, 2018).

\section{Waktu penelitian}

Penelitian dilaksanakan pada akhir November 2019 hingga akhir Juni 2020.

\section{Subjek Penelitian}

Populasi dalam penelitian ini adalah karyawan perusahaan start-up. Karakteristik subjek yang termasuk dalam populasi penelitian ini adalah karyawan perusahaan start-up yang menggunakan internet pada saat bekerja, memiliki kecukupan waktu dan kesediaan untuk mengisi kuesioner penelitian ini. Jumlah sampel yang diperoleh dalam penelitian ini berjumlah 66 karyawan dari perusahaan start-up yang berbeda.

\section{Teknik dan instrument pengumpulan data}

Penelitian ini menggunakan skala psikologis untuk pengumpulan data. Model skala yang digunakan oleh peneliti adalah skala model likert dengan 5 alternatif pilihan jawaban (tidak pernah, jarang, kadang, sering, dan selalu). Data dikumpulkan dengan menggunakan kuesioner online. Dua skala yang digunakan yaitu skala cyberloafing dan skala anteseden cyberloafing.

Skala cyberloafing dimodifikasi dari skala aktivitas yberloafing dan skala perilaku cyberloafing. Skala aktivitas cyberloafing menggunakan skala dari Li dan Chung (2006). Skala perilaku cyberloafing menggunakan skala yang disusun oleh Van Doorn (2011).

Skala anteseden cyberloafing dimodifikasi dari skala Mini-IPIP (Mini International Personality Item Pool) oleh Donnellan dkk. (2006), skala interference work and family oleh Carlson, Kacmar, \& Williams (2000), skala DISQ 3.0 (Demand Induced-Strain Questionnaire) De Jonge (2011), skala kebijakan organisasi oleh peneliti.

\section{Teknik Analisis data}

Sebelum dilakukan analisis utama, peneliti melakukan uji prasyarat analisis. Pada penelitian ini dilakukan uji normalitas dan linieritas sebagai prasyarat analisis.

\section{Uji Normalitas}

Penyebaran yang normal menggambarkan penyebaran data yang nyata sesuai dengan data sesungguhnya di lapangan (Setiawati, 2017). Uji normalitas pada penelitian ini dibantu oleh program SPSS for windows dengan formula One-Sample KolmogorovSmirnov. Hasil uji normalitas Kolomogorov-Smirnov menghasilkan nilai Kolmogorov-smirnov $\mathrm{Z}$ sebesar .875 dengan signifikansi lebih dari 0,05. Dengan demikian data berdistribusi normal

\section{Uji Linieritas}

Pengujian ini dilakukan untuk mengetahui linear atau tidaknya hubungan antara variabel bebas (sifat kepribadian, dukungan dan tuntutan kerja, gangguan pekerjaan dan keluarga, serta kebijakan perusahaan) dan variabel terikat (cyberloafing).

\section{Uji Multikolinieritas}

Pengujian ini dilakukan untuk mengetahui adanya korelasi antar-variabel. Dalam analisis regresi berganda, seharusnya tidak 
terdapat gejala multikolinearitas. Nilai tolerance $>0,10$ menunjukkan bahwa tidak ada gejala multikolinearitas yang terjadi dalam model regresi.

Tabel 1. Hasil uji linieritas

\begin{tabular}{lccc}
\hline \multicolumn{2}{c}{ Variabel } & Sig. & et \\
\multicolumn{1}{c}{ Bebas } & Terikat & & \\
\hline $\begin{array}{l}\text { Sifat } \\
\text { Kepribadian } \\
\text { Tuntutan dan }\end{array}$ & Cyberloafing & 0,284 & linear \\
$\begin{array}{l}\text { Dukungan } \\
\text { Kerja }\end{array}$ & & & \\
$\begin{array}{l}\text { Gangguan } \\
\text { Pekerjaan dan } \\
\text { Keluarga }\end{array}$ & Cyberloafing & 1,012 & linear \\
$\begin{array}{l}\text { Kebijakan } \\
\text { Organisasi }\end{array}$ & Cyberloafing & 0,032 & tidak \\
\hline
\end{tabular}

Tabel 2. Hasil uji multikolinearitas

\begin{tabular}{llc}
\hline \multicolumn{1}{c}{ Variabel } & \multicolumn{1}{c}{$\begin{array}{c}\text { Nilai } \\
\text { tolerance }\end{array}$} & et \\
\hline Sifat Kepribadian & 0,910 & tanpa gejala \\
$\begin{array}{l}\text { Tuntutan dan } \\
\text { Dukungan Kerja }\end{array}$ & 0,929 & tanpa gejala \\
$\begin{array}{l}\text { Gangguan Pekerjaan } \\
\text { dan Keluarga }\end{array}$ & 0,965 & tanpa gejala \\
Kebijakan organisasi & 0,955 & tanpa gejala
\end{tabular}

4. Uji Heteroskedastisitas

Pengujian ini dilakukan untuk mengetahui ada atau tidaknya ketidaksamaan variasi dari nilai residual satu pengamatan ke pengamatan lain. Dalam analisis regresi berganda seharusnya tidak terjadi gejala heteroskedastiitas. Nilai signifikansi $>0,05$ menunjukkan bahwa tidak terjadi gejala heteroskedastisitas dalam model regresi.

Tabel 3. Hasil uji heteroskedastisitas

\begin{tabular}{lcc}
\hline \multicolumn{1}{c}{ Variabel } & Sig. & et \\
\hline Sifat Kepribadian dan & 0,834 & tanpa gejala \\
$\begin{array}{l}\text { Tuntutan } \\
\text { Dukungan Kerja }\end{array}$ & & tanpa gejala \\
$\begin{array}{l}\text { Gangguan Pekerjaan } \\
\text { dan Keluarga }\end{array}$ & 0,622 & tanpa gejala \\
Kebijakan organisasi & 0,366 & tanpa gejala \\
\hline
\end{tabular}

Uji hipotesis dalam penelitian ini menggunakan analisis regresi linear berganda. Analisis regresi linear berganda adalah analisis prediksi dengan variabel prediktor $(\mathrm{X})$ yang diteliti berjumlah lebih dari satu (Setiawati, 2017). Penelitian ini akan menguji pengaruh variabel $\mathrm{X}$ anteseden cyberloafing (sifat kepribadian (X1), tuntutan dan dukungan kerja (X2), gangguan pekerjaan dan keluarga (X3), serta kebijakan perusahaan (X4) terhadap variabel $\mathrm{Y}$ cyberloafing baik secara simultan maupun partial.

\section{Hasil Penelitian dan Pembahasan}

Penelitian dilakukan pada 66 karyawan dari berbagai perusahaan start-up. Subjek terdiri dari 37 karyawan laki-laki dan 29 karyawan perempuan. Rata-rata karyawan yang menjadi subjek merupakan generasi $Z$ atau generasi milenial yang berusia 10 hingga 25 tahun. Hasil data deskriptif menunjukkan bahwa dalam perusahaan start-up lebih banyak didominasi oleh generasi Z, yang mana generasi ini memang sudah banyak menggunakan berbagai teknologi terutama internet. Hal ini dapat memungkinkan karyawan melakukan yberloafing di tempat kerja. Sesuai dengan pendapat Young (2010) yang menjelaskan bahwa karyawan dengan usia muda merasa lebih nyaman saat menggunakan internet dan menganggap internet lebih bermanfaat dibandingkan dengan karyawan dengan usia lebih tua. Didukung oleh data kategorisasi karyawan yang cenderung lebih tinggi pada perilaku pengembangan sebanyak $71,7 \%$. Selain itu, karyawan usia muda cenderung membangun kebiasaan yang mengarah pada penggunaan dan penyalahgunaan internet di tempat kerja (Ozler \& Polat, 2012). Terlihat dari frekuensi karyawan melakukan perilaku menyimpang sebanyak $71,2 \%$ dan perilaku kecanduan sebanyak $83,4 \%$.

Berdasar hasil yang diperoleh, membuktikan adanya cyberloafing pada 
karyawan perusahaan start-up baik dalam aktivitas maupun perilakunya. Hasil ini sesuai dengan penelitian sebelumnya (Van Doorn, 2011; Lim \& Chen, 2012; Ozler \& Polat, 2012). Tingkat keterlibatan karyawan dalam cyberloafing lebih besar pada aktivitas cyberloafing dibandingkan dengan keterlibatan pada perilaku cyberloafing. Dapat dilihat dari frekuensi aktivitas cyberloafing yang menunjukkan tingkat keterlibatan sedang cenderung tinggi sebanyak 46 karyawan $(69,7 \%)$. Sedangkan, frekuensi pada perilaku cyberloafing menunjukkan tingkat keterlibatan sedang cenderung rendah sebanyak 48 karyawan (72,8\%).

Penelitian ini membuktikan adanya pengaruh tuntutan dan dukungan kerja terhadap cyberloafing dan tidak ada pengaruh sifat kepribadian, gangguan pekerjaan dan keluarga, serta kebijakan perusahaan terhadap cyberloafing. Pengaruh diidentifikasi melalui analisis regresi linear berganda variabel anteseden cyberloafing (sifat kepribadian, tuntutan dan dukungan kerja, gangguan pekerjaan dan keluarga, serta kebijakan perusahaan) maupun variabel cyberloafing.

\section{Anteseden Individual}

Anteseden individual dilihat dari sifat kepribadian karyawan. Nilai signifkansi (Sig.) 0,073 pada variabel sifat kepribadian (X1) lebih besar dari 0,05 dapat diartikan bahwa tidak ada pengaruh sifat kepribadian terhadap cyberloafing. Nilai koefisien regresi pada variabel sifat kepribadian (X1) ditunjukkan dengan nilai $+0,484$ yang berarti bahwa apabila terjadi peningkatan sifat kepribadian (X1) satu satuan, maka akan terjadi peningkatan cyberloafing (Y) sebesar 0,484 .

Temuan ini tidak sesuai dengan penelitian Jia, Jia dan Karau (2013) serta Tresyagati (2014) bahwa sifat kepribadian memiliki hubungan terhadap cyberloafing terutama pada sifat kepribadian extraversion. Sebelumnya, Jia, Jia dan Karau (2013) menemukan bahwa karyawan dengan extraversion mengarahkan penggunaan internet untuk mencari interaksi sosial dengan orang lain. Selaras dengan salah satu ciri extraversion yang merupakan individu yang suka berteman. Penggunaan internet lebih berorientasi pada hal sosial untuk memperkuat ikatan sosial yang dimiliki oleh karyawan. Penelitian Tresyagati (2014) juga menemukan adanya hubungan negatif antara openness dengan cyberloafing. Perbedaan penemuan dalam penelitian ini, dikarenakan tidak diteliti lebih rinci sifat kepribadian secara terpisah (extraversion, conscienstiousness, neuroticism, agreeableness, dan openess), sehingga hasil yang ditemukan kurang sesuai dengan penelitian terdahulu.

Matthews (2008) mengingatkan bahwa hubungan antara sifat kepribadian dengan perilaku kontraproduktif (salah satunya cyberloafing) cenderung lemah dan tidak konsisten. Matthews (2008) juga mengatakan bahwa situasi kerja dapat memprediksi pengaruh kepribadian terhadap perilaku kontraproduktif (salah satunya cyberloafing). Sehingga dalam menafsirkan hasil penelitian ini perlu lebih berhati-hati. Dikarenakan belum ada kejelasan mengenai penemuan ini. Hal ini dapat menjadi salah satu pertimbangan bagi peneliti lain ketika akan meneliti terkait dengan pengaruh sifat kepribadian terhadap cyberloafing.

\section{Anteseden Pekerjaan}

Salah satu anteseden pekerjaan ditemukan berpengaruh terhadap cyberloafing yaitu tuntutan dan dukungan pekerjaan. Sedangkan anteseden pekerjaan lain yang tidak berpengaruh terhadap yberloafing adalah gangguan pekerjaan dan keluarga. Nilai signifikansi tuntutan dan dukungan kerja (X2) sebesar 0,002 <0,05 yang menunjukkan ada pengaruh tuntutan dan 
dukungan kerja terhadap cyberloafing. Tuntutan dan dukungan kerja diketahui mendapatkan nilai $\beta$ sebesar 0,603 terhadap cyberloafing. Hal ini menunjukkan terdapat pengaruh positif tuntutan dan dukungan kerja terhadap cyberloafing. Diartikan bahwa tuntutan dan dukungan kerja yang tinggi pada karyawan akan menyebabkan tingginya cyberloafing.

Penelitian Blanchard dan Henle (2008) menunjukkan bahwa karyawan yang mendapat tuntutan kerja tinggi akan menghasilkan kemungkinan peningkatan pada cyberloafing. Dilihat dari frekuensi karyawan pada kategorisasi skala anteseden cyberloafing bagian tuntutan dan dukungan kerja memperlihatkan karyawan memiliki tuntutan kerja yang cenderung tinggi dari tuntutan kognitif sebanyak $62,1 \%$, tuntutan emosional sebanyak $64.1 \%$, dan tuntutan fisik sebesar $71 \%$ dari total subjek karyawan. Sedangkan dukungan kerja pada karyawan mengarah pada kategori sedang cenderung rendah, baik pada dukungan emosional sebanyak 25,7\% maupun dukungan fisik 34,9\%, hanya dukungan kognitif yang masuk dalam kategori sedang cenderung tinggi yaitu sebesar $74,2 \%$ dari total subjek karyawan.

Lim (2002) mengatakan bahwa karyawan terlibat dalam perilaku menyimpang untuk menghindari pekerjaan yang dapat terjadi ketika tuntutan kerja melebihi dukungan kerja. Ini membuktikan keselarasan dengan hasil yang diperoleh peneliti yaitu tuntutan fisik yang tinggi memungkinkan karyawan telibat dalam perilaku menyimpang yang tinggi juga. Pada saat tuntutan kerja lebih tinggi dari dukungan kerja, dapat terjadi penurunan kesejahteraan karyawan sehingga pemulihan diperlukan untuk mendapatkan kembali dukungan kerja.

Tuntutan dan dukungan merupakan dua aspek pekerjaan yang dianggap terkait dengan job strain (ketegangan kerja)
(Schaufeli \& Bakker, 2004). Karyawan yang memiliki tuntutan kerja yang tinggi dibersamai dengan dukungan kerja yang tinggi dapat mengarahkan karyawan pada perilaku pengembangan, pemulihan maupun perilaku menyimpang. Situasi rendah maupun tinggi pada tuntutan dan dukungan kerja, tetap sama-sama memberikan kemungkinan karyawan melakukan yberloafing.

Anteseden pekerjaan lain, yaitu gangguan pekerjaan dan keluarga tidak ditemukan adanya pengaruh terhadap cyberloafing. Dengan nilai signifikansi $(\mathrm{p})>$ 0.05 diartikan bahwa tidak ada pengaruh gangguan pekerjaan dan keluarga terhadap cyberloafing. Nilai koefisien regresi pada variabel gangguan pekerjaan dan keluarga (X3) ditunjukkan dengan nilai $+0,188$ yang berarti bahwa apabila terjadi peningkatan gangguan pekerjaan dan keluarga (X3) satu satuan, maka akan terjadi peningkatan cyberloafing (Y) sebesar 0,188. Penelitian Van Doorn (2012) menemukan hubungan antara gangguan keluarga-pekerjaan dengan aktivitas cyberloafing, yang berarti karyawan yang lebih memprioritaskan keluarga dibanding pekerjaannya lebih banyak terlibat cyberloafing. Terdapat perbedaan hasil penemuan Van Doorn dengan penelitian ini. Namun Van Doorn (2012) menyebutkan bahwa studi sebelumnya belum pernah ada yang mengaitkan secara langsung antara gangguan pekerjaan dan keluarga dengan cyberloafing, sehingga keterkaitan antara gangguan pekerjaan dan keluarga perlu dilakukan penelitian lebih lanjut guna diperoleh hasil yang lebih beragam dengan penjelasan lebih banyak.

\section{Anteseden Organisasi}

Anteseden organisasi yang diteliti dalam penelitian ini adalah kebijakan perusahaan, yang mana didalamnya terdapat kebijakan penggunaan internet, kebijakan membawa perangkat keras pribadi dan kebijakan cara 
kerja baru. signifikansi (p) $>0,05$ menunjukkan tidak ada pengaruh kebijakan perusahaan terhadap gyberloafing. Nilai koefisien regresi pada variabel kebijakan perusahaan (X4) ditunjukkan dengan nilai $+0,488$ yang berarti bahwa apabila terjadi peningkatan kebijakan perusahaan (X4) satu satuan, maka akan terjadi peningkatan cyberloafing $(\mathrm{Y})$ sebesar 0,488. Meskipun hasil penelitian ini juga ditemukan berbeda dari hasil penelitian sebelumnya (Van Doorn, 2011; Ozler \& Polat, 2012), namun hal ini dapat dijelaskan dari data statistik yang diperoleh dari hasil kuesioner dan juga subjek yang digunakan dalam penelitian ini. Subjek dalam penelitian ini adalah karyawan perusahaan start-up, yang mana sesuai dengan karakteristik perusahaan start-up yang paling menonjol adalah penggunaan teknologi terutama internet dalam proses kerjanya. Diperkuat dengan data statistik yang memperlihatkan sebanyak 63,6\% karyawan menyatakan bahwa tidak ada kebijakan penggunaan internet di perusahaannya. Berbeda dari penelitian yang telah dilakukan oleh banyak peneliti sebelumnya yang meneliti pada perusahaan konvensional, tentu adanya kebijakan penggunaan internet seperti yang ditemukan Van Doorn (2011) serta Ozler dan Polat (2012) akan memiliki hubungan dengan penurunan cyberloafing.

Tidak adanya kebijakan perusahaan terkait penggunaan internet di tempat kerja dengan kombinasi kebijakan lain (membawa perangkat keras pribadi dan cara kerja baru) yang ada diperusahaan serta proses kerja yang mengharuskan karyawan banyak menggunakan internet, sehingga anteseden organisasi yaitu kebijakan perusahaan tidak lagi menjadi faktor yang mempegaruhi cyberloafing pada karyawan perusahaan start-up. Young (2010) mengatakan bahwa sistem kerja baru yang banyak menggunakan teknologi internet terutama pada karyawan muda memerlukan kebijakan perusahaan yang dapat diterima. Diperlukan inisiatif perusahaan untuk meningkatkan kepatuhan karyawan dalam bekerja guna membantu mengurangi penyalahgunaan internet di tempat kerja. Sehingga, meskipun tanpa kebijakan perusahaan terkait penggunaan internet di tempat kerja, perusahaan tetap dapat memastikan bahwa cyberloafing tidak akan merugikan perusahaan.

Berdasarkan hasil dan pembahasan yang telah dijelaskan, dapat disimpulkan bahwa anteseden cyberloafing yang digunakan dalam penelitian ini bertentangan dengan teori, kecuali anteseden tuntutan dan dukungan kerja. Hal ini dapat terjadi dikarenakan karakteristik subjek yang digunakan dalam penelitian ini berbeda dari penelitian sebelumnya. Subjek dalam penelitian ini tidak memiliki batas atau terikat peraturan tertentu dalam penggunaan internet di tempat kerja. Sehingga anteseden yang digunakan dalam penelitian ini tidak mempengaruhi karyawan start-up dalam melakukan cyberloafing di tempat kerja. Informasi ini dapat menjadi rujukan baru bagi peneliti lain yang ingin meneliti cyberloafing pada karyawan perusahaan start-up atau karyawan yang sudah terbiasa dengan penggunaan internet dalam proses kerjanya, agar nantinya peneliti tersebut dapat mencari anteseden yang lebih signifikan mempengaruhi cyberloafing.

\section{Simpulan dan Saran}

\section{Simpulan}

Berdasarkan hasil penelitian, ditarik kesimpulan berikut

1. Anteseden cyberloafing yang memiliki pengaruh terhadap yberloafing adalah tuntutan dan dukungan kerja. Anteseden lain yaitu sifat kepribadian, gangguan pekerjaan dan keluarga, serta kebijakan perusahaan tidak memiliki pengaruh terhadap cyberloafing. Berdasarkan hasil analisis regresi linear 
berganda tersebut, hipotesis 2 dalam penelitian ini dinyatakan diterima. Sedangkan hipotesis 1, 3, dan 4 dinyatakan ditolak

2. Variabel sifat kepribadian terbukti tidak memiliki pengaruh terhadap cyberloafing.

3. Variabel tuntutan dan dukungan kerja terbukti memiliki pengaruh terhadap cyberloafing.

4. Variabel gangguan pekerjaan dan keluarga terbukti tidak memiliki pengaruh terhadap cyberloafing.

5. Variabel kebijakan perusahaan terbukti tidak memiliki pengaruh terhadap cyberloafing.

6. Variabel sifat kepribadian, tuntutan dan dukungan kerja, gangguan pekerjaan dan keluarga serta kebijakan perusahaan secara simultan berpengaruh terhadap cyberloafing.

Saran

Berdasarkan hasil penelitian, peneliti memberikan saran kepada beberapa pihak.

1. Bagi organisasi

Salah satu anteseden cyberloafing yaitu tuntutan dan dukungan kerja. Oleh karena itu, organisasi atau perusahaan perlu bersama-sama menemukan solusi terbaik dari tuntutan kerja yang diberikan pada karyawan agar karyawan dapat menjalankan pekerjaan dengan baik tanpa melakukan cyberloafing di tempat kerja. Adapun sebenarnya internet di tempat kerja dapat menjadi solusi yang baik bagi pengembangan diri karyawan sehingga diperlukan manajemen yang tepat bagi perusahaan dalam penyediaan serta pemanfaatan internet ditempat kerja.

2. Bagi karyawan

Tingginya addiction behavior menjadi hal yang perlu diperhatikan karyawan. Penggunaan internet di tempat kerja dapat digunakan sebagaimana mestinya untuk media pengembangan diri.

3. Bagi peneliti selanjutnya

Penelitian selanjutnya dapat mengembangkan penelitian ini dengan lebih memperhatikan faktor lain yang mungkin akan memberikan kontribusi besar terhadap cyberloafing, mengingat penelitian cyberloafing sebagai konstruk multi-dimensi masih sangat sedikit diteliti.

\section{Daftar Pustaka}

Askew, Kevin Landon. (2012). The Relationship Between Cyberloafing and Task Performance and an Examination of the Theory of Planned Behavior as a Model of Cyberloafing. (Disertasi doktor filosofi, University of South Florida, 2012).

Asosiasi Penyelenggara Jasa Internet Indonesia (APJII). (2018). Penetrasi \& Profil Perilaku Pengguna Internet Indonesia. Jakarta: Polling Indonesia.

Blanchard, A. \& Henle, C. (2008). Correlates of Different Forms of Cyberloafing: The Role of Norms and External Locus of Control. Computers in Human Behavior, 1067-1084.

Buckner, J., Castille, C., \& Sheets, T. (2012). The Five Factor Model of Personality and Employees Excessive Use of Technology. Computers in Human Behavior, 1947-1953.

Carlson, D., Kacmar, K., \& Williams, L. (2000). Construction and Initial Validation of a Multidimensional Measure of Work-Family Conflict. Journal of Vocational Behavior, 249-276.

Colquitt, J., LePine, J., \& Wesson, M. (2015). Organizational Behavior. New York: McGraw-Hill Education.

De Jonge, Jan. (2011). DISQ 3.0 EN-Short: The DISC Questionnaire English Short Version 3.0. Netherland: 
Eindhoven University of Technology.

Donnellan, M., Oswald, F., Baird, B., et al. (2006). The Mini-IPIP Scales: TinyYet-Effective Measures of the Big Five Factors of Personality. Psychological Assessment, 192-203.

Jia, H., Jia, R., \& Karau, S. (2013). Cyberloafing and Personality: The Impact of the Big Five Traits and Workplace Situational Factors. Journal of Leadership \& Organizational Studies XX $(\mathrm{X}), 1-8$.

Li, S.-M. \& Chung, T.-M. (2006). Internet Function and Internet Addictive Behavior. Computers in Human Behavior, 1067-1071.

Lim, V. (2002). The IT Way of Loafing on The Job: Cyberloafing, Neutralizing, and Organizational Justice. Journal of Organizational Behavior, 675694.

Lim, V. \& Chen, D. J. (2012). Cyberloafing at the Workplace: Gain or Drain on Work. Behaviour and Information Technology Vol. 31, Issue 4, 343353.

Lim, V. \& Teo, T. (2005). Prevalence, Perceived Seriousness, Justification and Regulation of Cyberloafing in Singapore an Exploratory Study. Information and Management, 1081-1093.

Matthews, G. (2008). Personality and information processing: A cognitive-adaptive theory. In G. J. Boyle, G. Matthews \& D. H. Saklofske (Eds.), The SAGE Handbook of personality theory andassessment. Volume 1: Personality theories and models (pp 56-79). Thousand Oaks, CA: Sage.

Ozler, D. E., \& Polat, G. (2012). Cyberloafing Phenomenon in Organizations: Determinant and Impacts. International Journal of eBusiness and eGovernment Studies, 4 (2) 1 15.

Perdani, M. D., Widyawan, \& Santoso, P. I. (2018). Faktor-faktor yang Mempengaruhi Pertumbuhan Startup di Yogyakarta. Seminar Nasional Teknologi dan Komunikasi , 337-349.

Rajah, R., \& Lim, V. K. (2011). Cyberloafing, Neutralization, and Organizational Citizenship Behavior. Pacific Asia Conference on Information Systems (PACIS), 152

Ries, E. (2018). The Lean Startup (Republish). Yogyakarta: Bentang Pustaka.

Schaufeli, W. \& Bakker, A. (2004). Job Demand, Job Resources, and Their Relationship with Burnout and Engagement: a Multi-sampel Study. Journal of Organizational Behavior, 293-315.

Setiawati, F. A. (2017). Statistika Terapan. Yogyakarta: Parama Publishing.

Tresyagati. (2014). Hubungan Dimensi Kepribadian Big Five dengan Perilaku Minor Cyberloafing. Skripsi psikologi, Universitas Sumatera Utara.

Van Doorn, O. N. (2011). Cyberloafing: A Multi-dimensional Construct Placed in a Theoretical Framework. Tesis master, Eindhoven University of Technology.

Young, K. (2010). Policies and Procedures to Manage Employee Internet Abuse. Computers in Human Behavior, 1467-1471.

Yudhanto, Y. (2018). Information Technology Business Start-Up. Jakarta: PT. Elex Media Komputindo. 